\title{
International Journal of Medicine and Public Health [IJMEDPH] is now published by EManuscript
}

\section{Mueen Ahmed KK}

\section{Mueen Ahmed KK \\ Managing Editor \\ Phcog.Net, Phcog.Net, \#17, II Floor, Bud- dha Vihar Road Cox Town, Bangalore 560046 , INDIA. \\ Correspondence \\ Dr. Mueen Ahmed KK}

Phcog.Net, Phcog.Net, \#17, II Floor, Buddha Vihar Road Cox Town, Bangalore 560 046, INDIA.

Email: journals@phcog.net

\section{History}

- Submission Date: 05-06-2016;

- Accepted Date: 20-06-2016.

DOI : 10.5530/ijmedph.2016.2.2

Article Available online http://www.ijmedph.org/v6/i2

\section{Copyright}

(C) 2016 Phcog.Net. This is an open-access article distributed under the terms of the Creative Commons Attribution 4.0 International license.
The year 2016 is an important milestone for International Journal of Medicine and Public Heath [IJMEDPH] (www.ijmedph.org) as it is entering 5th year. It is known as one of the peer-reviewed medicine and Public Health journal and I am pleased to present you this issue being published by EManuscript (A Publishing division of Phcog. Net). The new issue content for volume 5 is available "http://www.ijmedph.org" and archives are also available in the same link. IJMEDPH is now built with the responsive website the site can be easily browsed on mobile devices, tablets, and desktop screens.

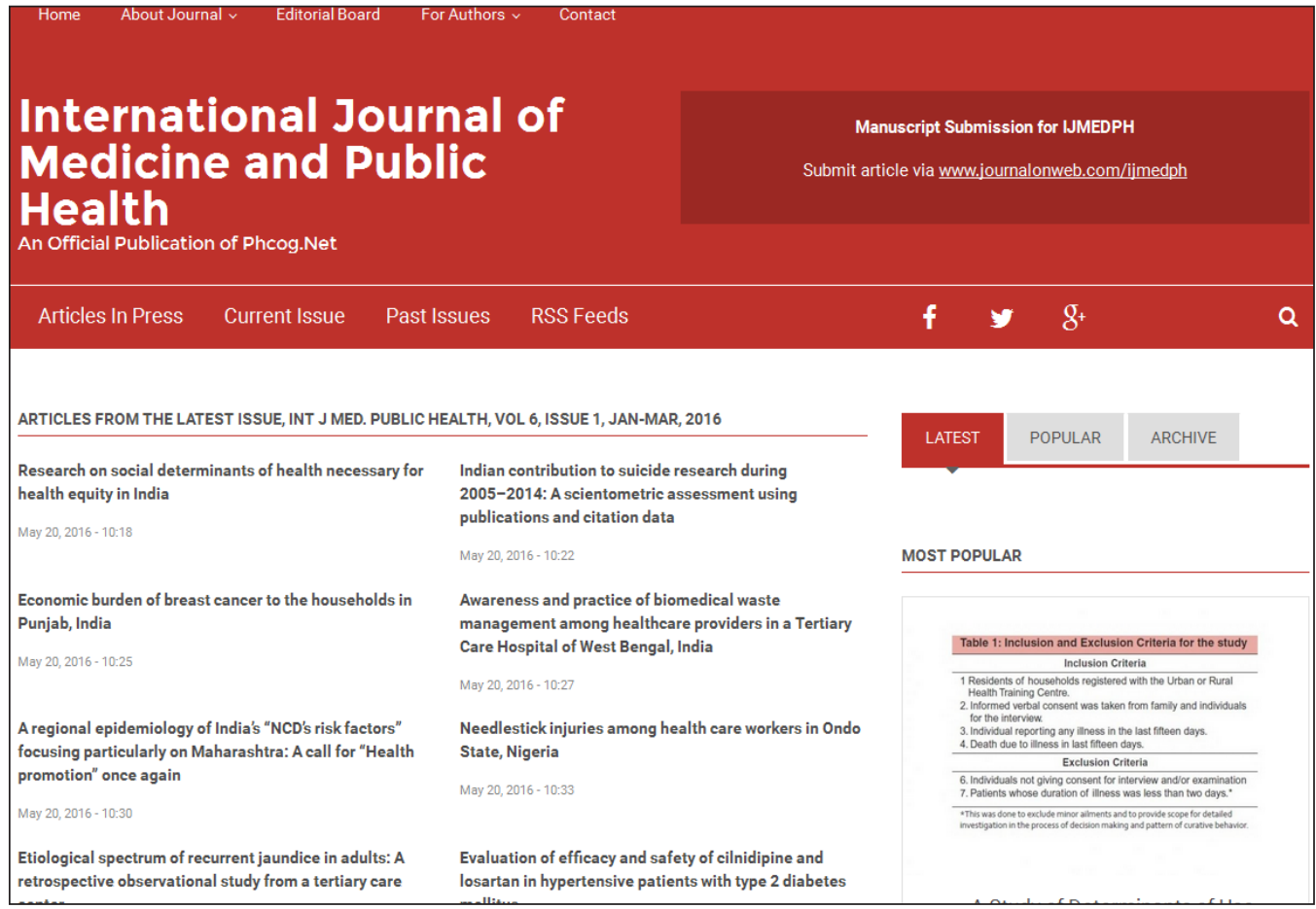

\section{ABOUT PHCOG.NET}

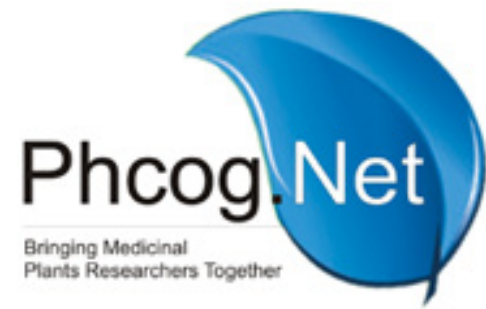

Founded in the year 2004, as the PHCOG.NET a private organization dedicated to Natural Products
Research leading to develop promising drugs. Our main mission is to make information on herbal drug research readily available in different formats to suit the individual needs.

Phcog.Net - A Platform for Natural Product Researchers was created to combat problems and update the latest research. It makes innovative use of the best tools for information dissemination to overcome the hurdles to Natural Product Research. Phcog.Net is a private organization dedicated to Natural Products Research in order to develop promising drugs.
Cite this article : Mueen Ahmed KK. International Journal of Medicine and Public Health [IJMEDPH] is now published by EManuscript. Int. J. Med. Public Health, 2016; 6(2):59-60. 


\section{CO-BRANDS : SCIBIOLMED.ORG (SCIENTIFIC DIVISION OF PHCOG.NET) | EMANUSCRIPT (A PUBLISHING UNIT OF PHCOG.NET)}

\section{Phcog.Net Journals}

Published by Wolters-Kluwer Health

- Pharmacognosy Magazine

http://www.phcog.com

- Pharmacognosy Research http://www.phcogres.com

- Pharmacognosy Reviews

http://www.phcogrev.com

- Journal of Pharmacology and Pharmacotherapeutics

http://www.jpharmacol.com

- International Journal of Pharmaceutical Investigation http://www.jpionline.org

- Journal of Pharmaceutical Negative Results

http://www.pnrjournal.com

- Journal of Natural Science, Biology and Medicine http://www.jnsbm.org

- International Journal of Clinical and Experimental Physiology http://www.ijcep.org

Published by EManuscript

- Pharmacognosy Journal

http://www.phcogj.com

- Pharmacognosy Communications

http://www.phcogcommn.org

- Free Radicals and Antioxidants

http://www.antiox.org

- Journal of Young Pharmacists

http://www.jyoungpharm.org

- Pharmaceutical Methods

http://www.phmethods.net

- Systematic Reviews in Pharmacy

http://www.sysrevpharm.org

- Journal of Cardiovascular Disease Research

http://www.jcdronline.org

- International Journal of Medicine and Public Health

http://www.ijmedph.org

- Journal of Contradicting Results in Science

http://www.jcrsci.org

- Journal of Scientometric Research

http://www.jscires.org

- Biology, Engineering, Medicine and Science Reports (BEMS Reports)

http://www.bemsreports.org

- Oncology, Gastroenterology and Hepatology Reports (OGH Reports)

http://www.oghreports.org

- PTB Reports (Pharmacology, Toxicology and Biomedical Reports)

http://www.ptbreports.org

\section{ABOUT SCIBIOLMED.ORG}

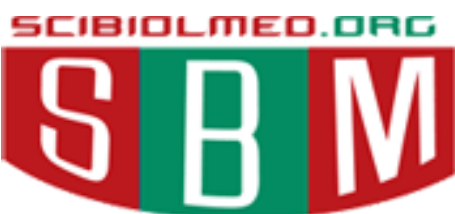

ScibiolMed.Org (www.scibiolmed. org) - A scientific division of Phcog.Net dedicated to Research in the field of Science, Biology and Medicine. Its main mission is to enable those who seek the relevant research information on Science,

Biology and Medicine and make them available in different formats to suit their individual needs. A long term objective is to provide high quality, accurate and required information to enhance research and innovative concepts in scholarly publishing.

Visit www.scibiolmed.org for more details

\section{ABOUT EMANUSCRIPT}

\section{- Manuscript}

sion of Phcog.Net) assists offline journals transforming them into world class online journals. We are committed to meeting the needs of the academic and professional communities at the same time working to define and meet the information needs of journal publishing industry.

We specialize in providing services to the journal publishing industry and understand the importance of short turnaround times and quality electronic delivery requirements (SGML / XML, Web PDF) to your business. EMS is a full-service publishing vendor specializing in a range of services including software development, data conversion, XML solutions, copy editing, typesetting, proofreading, graphic production and complex e-deliverables. It currently publishes more than 20 journals for different organizations and societies.

Visit - www.emanuscript.in for more details.

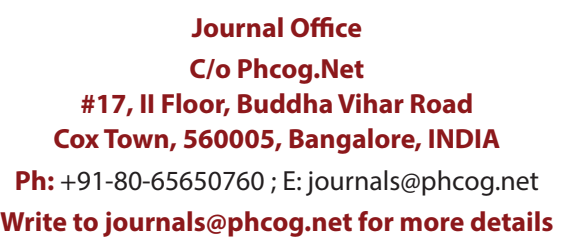

Journal Office

hcog.Net

\#17, II Floor, Buddha Vihar Road

Ph: +91-80-65650760; E: journals@phcog.net

Write to journals@phcog.net for more details 